\title{
DEVELOPMENT OF HAPLOID PLANTS THROUGH OVARY CULTURE TECHNIQUE IN WHEAT ( Triticum aestivum L ).
}

\author{
H. A. Abo Shama; Y. M. Yaseen and Hala S. Ghareeb \\ Plant Biotech. Department Genetic Engineering and Biotech. Research \\ Institute ( GEBRI ), Sadat City. Univ. Menufyia, Egypt.
}

\begin{abstract}
This research was done at department of Plant Biotechnology, Genetic Engineering and Biotechnology Research Institute( GEBRI), Sadat City university, Menufyia, Egypt from 2009 to 2014 years to study the effect of four factors affected callus induction of ovary cultur i.e.(cold pretreatment, chemical pretreatments, growth regulators and spikes sources. and establishment a technique to produce haploid plants. Three wheat varieties were used, Sids 1, Gemmeiza 9 and Giza 168. The results indicated that, chemical pretreatments by sterilization substances (Ethanol alcohol $70 \%$ or Mercurec chloride $1 \mathrm{~g} / \mathrm{L}$ or Thiourea $2 \mathrm{~g} / \mathrm{L}$ ) were very important and essential to induce calli from ovaries. The combination between ( 1 and $2 \mathrm{mg} / \mathrm{L} \mathrm{2,4-D})$ and $(0,0.1$ and $0.2 \mathrm{mg} / \mathrm{L}$ kinetien) gave the highest response of callus induction and plant regeneration percentages. The estimates were increased and developed with increasing the cultured area which the spiks were collected from it. The estimates were varied with varieties.
\end{abstract}

Key words: Wheat, Ovary culture, Cold \& chemical pretreatments, Growth regulators, Source of spikes, Varieties.

\section{INTRODUCTION}

Unpollinated ovary culture as a one of haploid production techniques has some advantages, it is an easy technique and produce more green plants than anther culture. This technique didn't take enough interest from researchers. The researchers believe that the cold pretreatment is very important to callus induction from megaspors, whenever they use another strongest treatment when they sterilize the spikes with chemical substances, so we must separated the cold and the chemical pretreatments, this can be applied during ovary culture process without sterilization, specially the spike is covered with the leaf sheath at the booting stage. The frequency of gynogenesis is low so increasing frequency is the ultimate goal, the highest variance was found among the spikes of different plants, so we must collect the spikes from a big cultured area. 2, 4-D was affected the cultivars 
gynogenesis abilities (Madarhri-Alaoui et al., 1998 and Alaoui et al., 2005). Gynogenesis is variety dependant, many researchers were in agreement with this (Erezhenov et al., 1991; Alaoui et al., 2005; Salama- Ayed and Slim Amara, 2007 and Ayed et al., 2010). So most researchers directed to the distant hybridization via chromosome elimination methods.

The main objective of this study was to produce haploid plants by ovary culture via determined some treatments which affected on it.

\section{MATERIALS AND METHODS}

Seeds of the Three Egyptian wheat varieties, Sids 1, Gemmeiza 9 and Giza 168, which obtained from Agriculture Research Station, Gemmeiza, Tanta, Gharbeiya, Egypt were sown at plots 6 sq.m at the experimental farm of (GEBRI). Spikes were collected at the booting stage when the awn just emerged and just before the sheath opening, this morphological shape indicate the uninuclate stage in development of the pollen grains. leaves were removed and the stems were cut at $4 \mathrm{~cm}$ below the first node prior to the spike, spikes inside the sheath were washed by tap water and dried with paper towel, spikes were covered with aluminum foil and kept at $3 \pm 1 \mathrm{C}^{0}$. Before inoculation at laminar flow spikes were immersed in Ethanol alcohol $70 \%$ at just below the first node prior to the spikes for 6 hours (except the experiment of cold pretreatment), these experiments were carried out with out sterilization, spikes were pulled from the sheath carefully, ovaries were excised and plated at jars each one contains $20 \mathrm{ml}$ of induction medium (modified MS medium $+2 \mathrm{mg} / \mathrm{L}$ 2,4-D+0.1 mg /L kin +90 $\mathrm{gm} / \mathrm{L}$ maltose). The ovary culture medium used in this study was based on published work in wheat (Henry and De Buyser, 1985) with some modification regarding to the kind and concentration of sugar and growth regulators. Inoculated jars were transferred to the dark at $26 \mathrm{C}^{0}$ for 4 weeks. Then jars with swelling ovaries were transferred to the light. After two weeks a creamy white callus grew out of the base of the ovary from which it was detached. Callus aged about 4 weeks were transferred to the regeneration medium $(\mathrm{MS}+0.2 \mathrm{mg} / \mathrm{L}$. BA+200 $\mathrm{mg} / \mathrm{L}$ glutamin+30 $\mathrm{g} / \mathrm{L}$. sucrose). The regenerates were counted.

The studied treatments :-

1 - Cold pretreatment: Spikes were kept at $3 \pm 1 \mathrm{C}^{\mathrm{o}}$ for $(4,8,12,16,20$, 24 and 28 days) before inoculation at modified MS medium+ $2 \mathrm{mg} / \mathrm{L} 2,4-\mathrm{D}$ $+0.1 \mathrm{mg} / \mathrm{L}$ kinetin $+90 \mathrm{~g} / \mathrm{L}$ maltose . 
2- Chemical pretreatments: Spikes were immersed in (Ethanol alcohol 70 $\%$ or Mercurec chloride $1 \mathrm{~g} / \mathrm{L}$ or Thiourea $2 \mathrm{~g} / \mathrm{L}$ ) for 3,6 , and 9 hours before inoculation at modified MS medium $+2 \mathrm{mg} / \mathrm{L} 2,4-\mathrm{D}+0.1 \mathrm{mg} / \mathrm{L}$ kinetin 90 $\mathrm{g} / \mathrm{L}$ maltose.

3 - Growth regulators: Ovaries were plated at induction medium modified MS medium with combination of $(0,0.5,1.0,2.0$ and $3.0 \mathrm{mg} / \mathrm{L} \mathrm{2,} \mathrm{4-}$ D) and $(0,0.1$ and $0.2 \mathrm{mg} / \mathrm{L}$ kinetin $)+90 \mathrm{gm} \mathrm{L}$ maltose.

4- Source of spikes: Spikes of the three wheat varieties were collected from three sources:

(A) Plots, which were sown with seeds from harvesting plots of the last year.

(B) Plots which were sown with seeds from Agriculture Research Station.

(C) Open field which were sown with the same varieties.

Ovaries from the previous three sources of three wheat varieties were plated at modified MS medium + 2mg /L 2,4-D + $0.1 \mathrm{mg} / \mathrm{L}$ kinetin +90 $\mathrm{gm} / \mathrm{L}$ maltose.

\section{RESULTS AND DISCUSSION}

\section{1-Effect of cold pretreatment period on ovary response ( callus count\%) of wheat varieties.}

The results in Table 1, show the effect of cold pretreatment at $3.0 \pm 1 \mathrm{C}^{0}$ period on ovary response of the studied wheat varieties. All cold pretreatment periods had no effect on ovary response of the three wheat varieties, these results may be explained by, the cold pretreatment do not act as a stress as enough to switch on the genes which were responsible for the embryogenic bathway at megaspores. Unsuitable pretreatments hide the effect of medium and varieties. These results in contrast with those obtained by Sibi et al., (2001) and Tsegaye Getahun et al. (2013).

\section{2-Effect of chemical pretreatments on ovary response (callus count \% and regeneration \%) of wheat varieties:}

Presented data in Table 2 clear the effect of chemical pretreatments on ovary response ( callus count $\%$ and regeneration $\%$ ) of wheat varieties It could be noticed that ovary response differed between the studied varieties. Six hours was the best period to immerse the stem of the spike in the three chemicals to induce the embryogenic pathway at megaspores .Ethanol alcohol is considered the relatively best chemical pretreatments in comparison to the other two chemicals followed by mercurec chloride and thiourea in both estimates ( callus count and regeneration percentages). With respect to the effect of wheat varieties, Sids 1 recorded the highest callus 
Table 1: Effect of cold pretreatment period on ovary response (callus count \%) of wheat varieties.

\begin{tabular}{|c|c|c|c|}
\hline $\begin{array}{c}\text { Cold } \\
\text { pretreatments } \\
\text { Period/day }\end{array}$ & Sids 1 & Gemmeiza 9 & Giza 168 \\
\cline { 2 - 4 } & 0 & 0 & 0 \\
\hline \hline 4 & 0 & 0 & 0 \\
\hline 8 & 0 & 0 & 0 \\
\hline 12 & 0 & 0 & 0 \\
\hline 16 & 0 & 0 & 0 \\
\hline 20 & 0 & 0 & 0 \\
\hline 24 & 0 & 0 & 0 \\
\hline 28 & & & \\
\hline
\end{tabular}

Table 2 : Effect of chemical pretreatments on ovary response (callus count $\%$ and regeneration $\%$ ) of wheat varieties.

\begin{tabular}{|c|c|c|c|c|c|}
\hline \multicolumn{2}{|c|}{ Treatments } & \multicolumn{4}{|c|}{ Callus count $\%$} \\
\hline \multirow[t]{2}{*}{ Varieties } & \multirow{2}{*}{$\begin{array}{c}\text { Chemical } \\
\text { pretreatments }\end{array}$} & \multicolumn{3}{|c|}{ Immersion time } & \multirow{2}{*}{$\begin{array}{c}\text { Regeneration } \\
\%\end{array}$} \\
\hline & & (3) & (6) & (9) & \\
\hline \multirow{3}{*}{ Sids 1} & $\mathrm{C}_{2} \mathrm{H}_{5} \mathrm{OH}$ & 0 & 13.6 & 0 & 0 \\
\hline & $\mathrm{Hg} \mathrm{Cl}_{2}$ & 0 & 11.2 & 0 & 0 \\
\hline & $\mathrm{CH}_{4} \mathrm{~N}_{2} \mathrm{~S}$ & 0 & 10.4 & 0 & 0 \\
\hline \multirow{3}{*}{$\begin{array}{c}9 \\
\text { Gemmeiza }\end{array}$} & $\mathrm{C}_{2} \mathrm{H}_{5} \mathrm{OH}$ & 0 & 8.8 & 0 & 0 \\
\hline & $\mathrm{Hg} \mathrm{Cl}_{2}$ & 0 & 6.4 & 0 & 0 \\
\hline & $\mathrm{C} \mathrm{H}_{4} \mathrm{~N}_{2} \mathrm{~S}$ & 0 & 6.4 & 0 & 0 \\
\hline \multirow[t]{3}{*}{ Giza 168} & $\mathrm{C}_{2} \mathrm{H}_{5} \mathrm{OH}$ & 0 & 10.4 & 0 & $\begin{array}{l}100 \text { partial } \\
\text { regeneration }\end{array}$ \\
\hline & $\mathrm{Hg} \mathrm{Cl}_{2}$ & 0 & 8.0 & 0 & $\begin{array}{c}100 \text { partial } \\
\text { regeneration }\end{array}$ \\
\hline & $\mathrm{C} \mathrm{H}_{4} \mathrm{~N}_{2} \mathrm{~S}$ & 0 & 7.2 & 0 & 0 \\
\hline
\end{tabular}




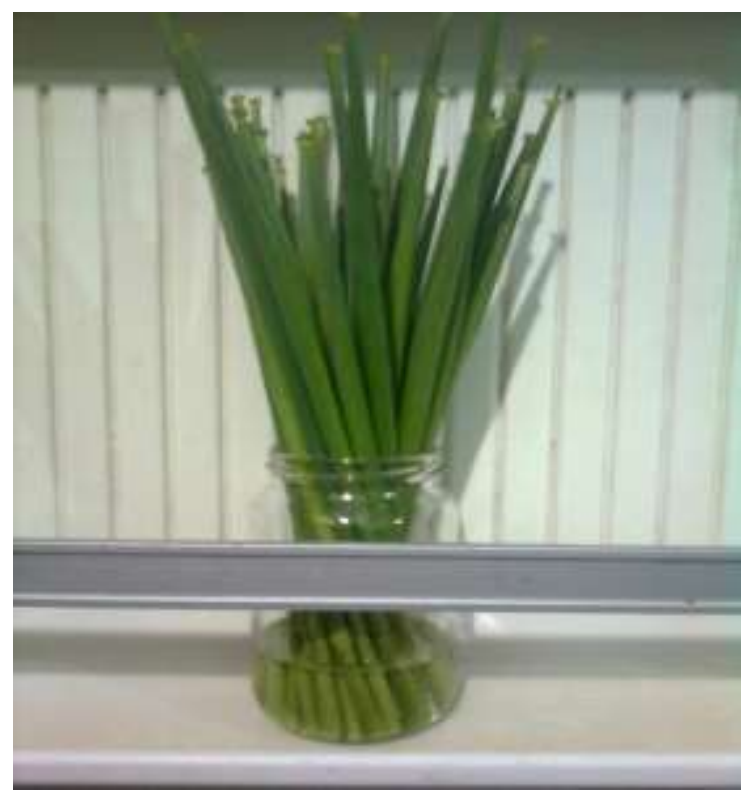

Figure1. Chemical pretreatment

count percentage but Gemmeiza 9 was the lowest one, Giza 168 was the only variety which exhibited partial regeneration. Every one used sterilization is considered used the previous chemical pretreatments.

\section{3-Effect of growth regulators concentrations on ovary response( callus count\% and regeneration\%) of wheat varieties:}

The common observation of data at Table 3 is the frequency of ovary response of the three wheat varieties is low and the regenerates to plants do not happen, just partial regeneration only at Giza168 variety (Figure 3) .These results may be due to the spikes were collected from a small cultured area ( plots which were sown with seeds from Agriculture research station) and the general frequency of ovary response is low and the highest variance was found among the spikes of different plants.

Giza 168 variety is the only variety which exhibit regeneration, this Could be due to the regeneration is higher heritability character than Callus formation .Giza 168 variety is considered the highest variety in response to ovary culture, Gemmeiza 9 variety is the lowest one meanwhile Sids 1 is the intermediate. Generally, the combination between ( $1 \mathrm{mg} / \mathrm{L}$ 2,4-D , 2 $\mathrm{mg} / \mathrm{L}$ 2,4-D ) and ( $0,0.1$ and $0.2 \mathrm{mg} / \mathrm{L}$ kinetin ) recorded the best results for callus count and regeneration percentages for the three wheat varieties. These results are in agreements with those obtained by ( Madarhri - Alaoui 
Table 3: Effect of growth regulators on ovary response (callus count \% and regeneration $\%$ ) of wheat varieties .

\begin{tabular}{|c|c|c|c|c|c|c|c|}
\hline \multirow{2}{*}{\multicolumn{2}{|c|}{ Treatments }} & \multicolumn{6}{|c|}{ Varieties } \\
\hline & & \multicolumn{2}{|c|}{ Sids 1} & \multicolumn{2}{|c|}{ Gemmeiza 9} & \multicolumn{2}{|c|}{ Giza 168} \\
\hline $\begin{array}{c}\text { Kin } \\
\mathrm{mg} / \mathrm{L}\end{array}$ & $\begin{array}{l}\text { 2,4-D } \\
\mathrm{mg} / \mathrm{L}\end{array}$ & $\begin{array}{c}\text { Callus } \\
\text { count } \\
\%\end{array}$ & $\begin{array}{c}\text { Regeneration } \\
\%\end{array}$ & $\begin{array}{c}\text { Callus } \\
\text { count } \\
\%\end{array}$ & $\begin{array}{c}\text { Regeneration } \\
\%\end{array}$ & $\begin{array}{c}\text { Callus } \\
\text { count } \\
\%\end{array}$ & $\begin{array}{c}\text { Regeneration } \\
\%\end{array}$ \\
\hline \multirow{5}{*}{0.0} & 0.0 & 0 & 0 & 0 & 0 & 0 & 0 \\
\hline & 0.5 & 0 & 0 & 0 & 0 & 0 & 0 \\
\hline & 1.0 & 15.2 & 0 & 0 & 0 & 18.4 & $\begin{array}{l}100 \text { partial } \\
\text { regeneration }\end{array}$ \\
\hline & 2.0 & 40 & 0 & 12 & 0 & 18.4 & $\begin{array}{l}100 \text { partial } \\
\text { regeneration }\end{array}$ \\
\hline & 3.0 & 0 & 0 & 10.4 & 0 & 18.4 & 0 \\
\hline \multirow{5}{*}{0.1} & 0.0 & 0 & 0 & 0 & 0 & 0 & 0 \\
\hline & 0.5 & 0 & 0 & 0 & 0 & 0 & 0 \\
\hline & 1.0 & 10.4 & 0 & 0 & 0 & 0 & 0 \\
\hline & 2.0 & 15.2 & 0 & 0 & 0 & 22.4 & 0 \\
\hline & 3.0 & 0 & 0 & 0 & 0 & 0 & 0 \\
\hline \multirow{5}{*}{0.2} & 0.0 & 0 & 0 & 0 & 0 & 0 & 0 \\
\hline & 0.5 & 5.6 & 0 & 0 & 0 & 0 & 0 \\
\hline & 1.0 & 15.2 & 0 & 0 & 0 & 11.2 & 0 \\
\hline & 2.0 & 16.8 & 0 & 0 & 0 & 7.2 & 0 \\
\hline & 3.0 & 0 & 0 & 0 & 0 & 0 & 0 \\
\hline
\end{tabular}

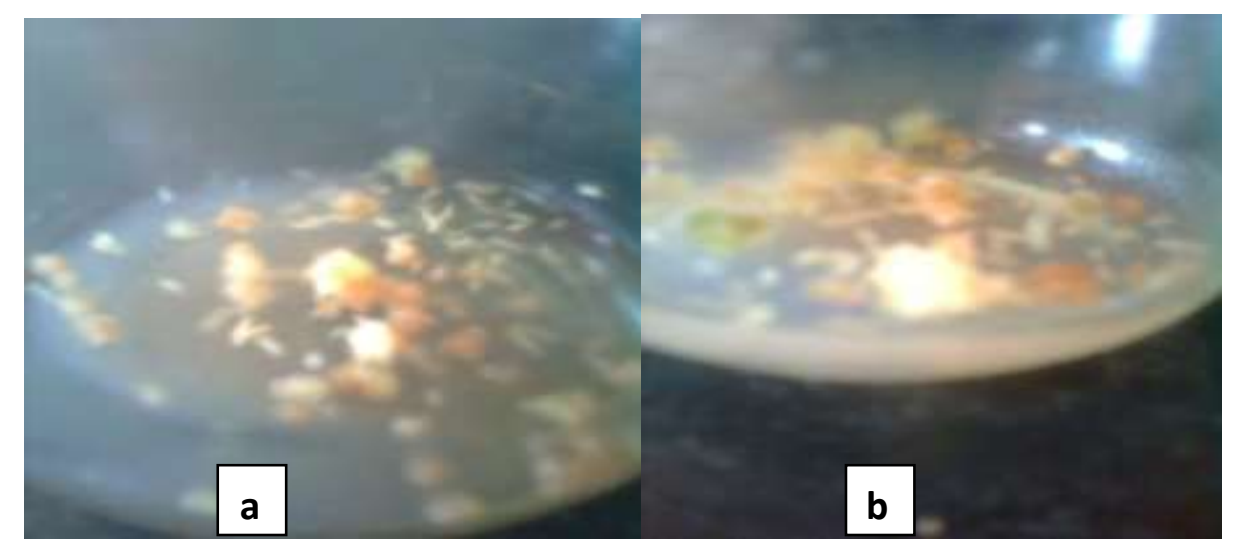




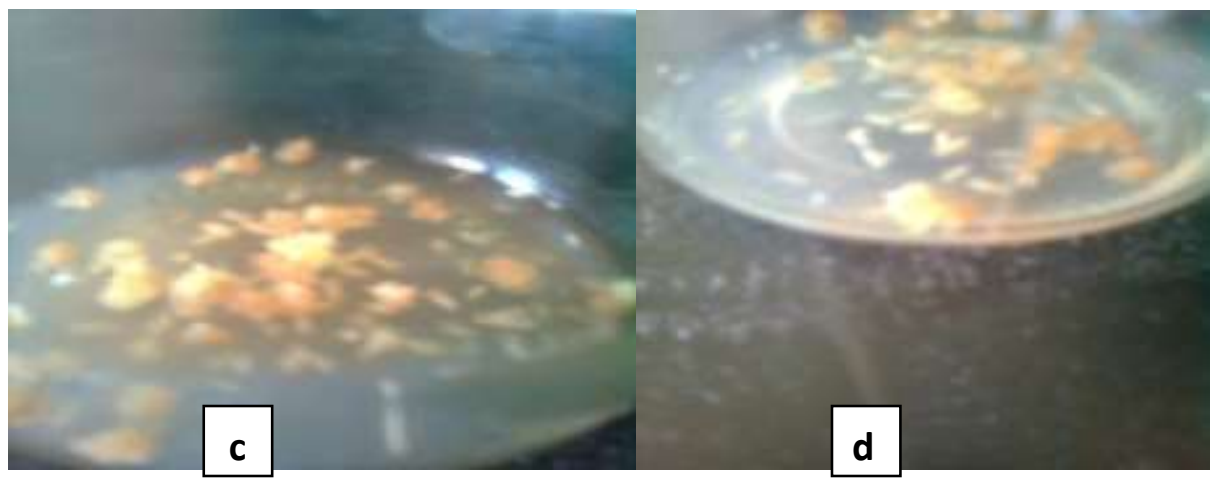

Figure 2 : Callus of ovary
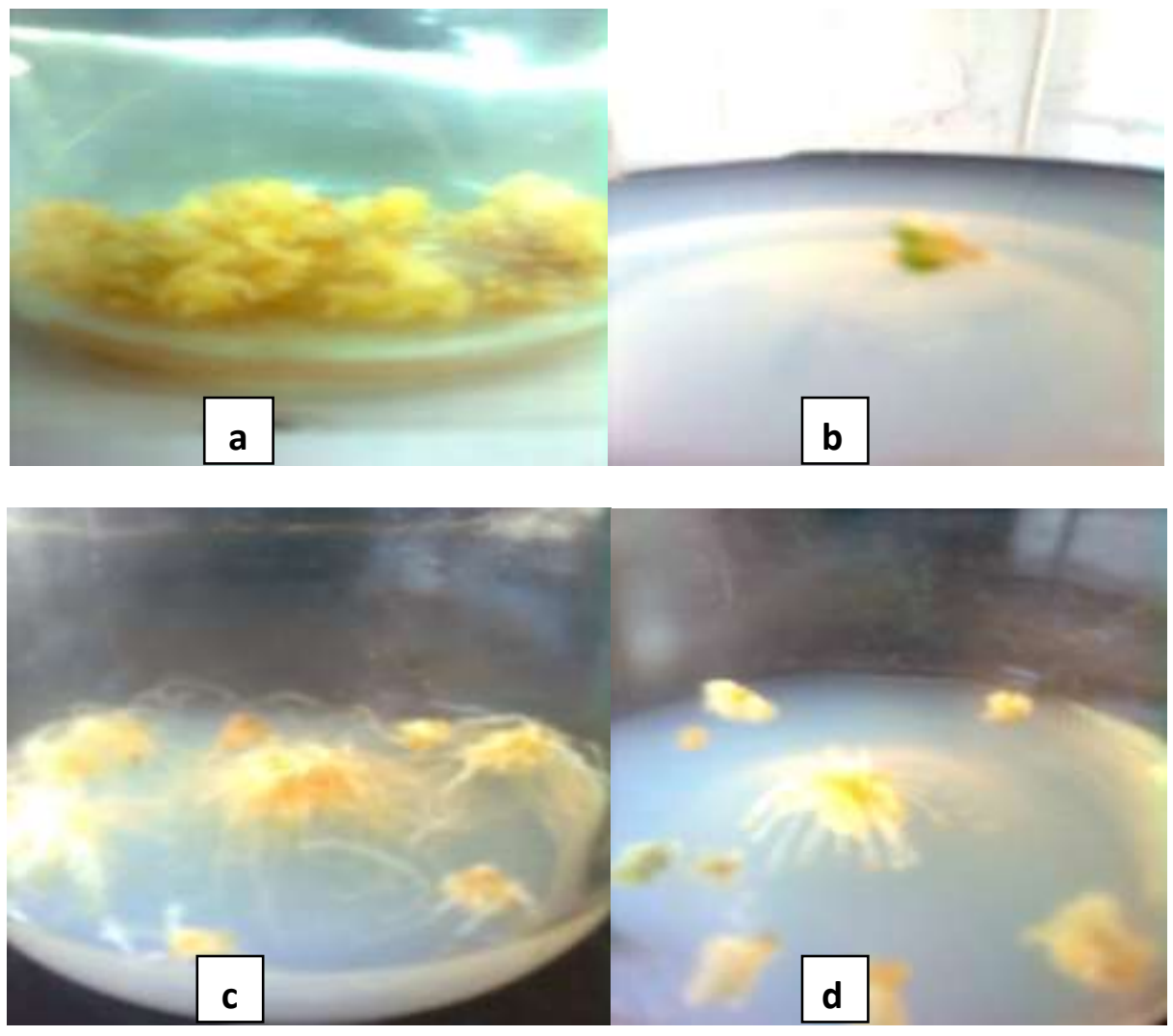

Figure 3 : Regeneration 
et al., 1998; Alaoui et al., 2005 and Tsegaye Getahun et al ., 2013). Low concentration of 2,4-D is not enough to cell division but high concentration of 2,4-D leads to elongation of the cell without division and the toxic of 2,4D exhibit.

\section{4-Effect of source of spikes on ovary response (callus count \% and regeneration \% )of wheat varieties:}

Data in Table 4 show the ovary callus count and regeneration percentages as affected by wheat varieties and spike sources.

Spikes of wheat variety sids 1 which obtained from source $\mathrm{C}$ produced the highest percentage of callus count $(47.2 \%)$ followed by spikes of the same variety which obtained from the source B $(40 \%)$. On the other hand spikes of Gemmeiza 9 variety from source A have $(0.8 \%)$ of callus count. Sids1 variety surpass the other varieties in callus count percentage meanwhile Gemmeiza 9 variety was the last.

Table 4 : Effect of source of spikes on ovary response( callus count $\%$ $\%$ and regeneration $\%$ ) of wheat varieties .

\begin{tabular}{|c|c|c|c|}
\hline Varieties & $\begin{array}{c}\begin{array}{c}\text { Source of } \\
\text { spikes }\end{array} \\
\end{array}$ & $\begin{array}{c}\text { Callus count } \\
\%\end{array}$ & $\begin{array}{c}\text { Regeneration } \\
\%\end{array}$ \\
\hline \multirow{3}{*}{ Sids 1} & $\overline{\mathbf{A}}$ & 14.4 & 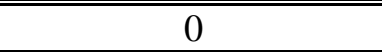 \\
\hline & B & 40.0 & 0 \\
\hline & $\mathbf{C}$ & 47.0 & 0 \\
\hline \multirow{3}{*}{ Gemmeiza 9} & $\mathbf{A}$ & 0.8 & 0 \\
\hline & B & 12.0 & 0 \\
\hline & $\mathrm{C}$ & 16.8 & 0 \\
\hline \multirow{3}{*}{ Giza 168} & $\mathbf{A}$ & 8.8 & 100 Roots \\
\hline & B & 18.4 & 100 Partial regeneration \\
\hline & $\mathbf{C}$ & 23.2 & 0.03 Green zone \\
\hline
\end{tabular}

A : Plots which were sown with seeds from harvesting plots of the last year.

B : Plots which were sown with seeds from Agriculture Research Station .

$\mathrm{C}$ : Open field which were sown with the same varieties .

From the same Table 4 regeneration percentage of Giza 168 variety which obtained from the source $\mathrm{C}$ is considered the best regeneration (green zone, Figure $3 b$ ) followed by the regeneration of the same variety from the source B (partial regeneration, Figure 3a) and the regeneration from the source A (roots, Figure.3c, d) of the same variety. The regeneration exhibit only at Giza 168, this may be due to the regeneration is higher heritability character than callus formation . The regeneration to plants don,t 
exhibit at the three varieties, this could be attributed to the uninuclate is unsuitable stage for ovary culture.

From these results callus count and regeneration percentages differed according to wheat variety and spikes sources while as the selection area of spikes increased callus count increased and the regeneration improved from roots to partial regeneration to green zone.

\section{REFERENCES}

Alaoui, M. M. D. ; Moussa - Labep ; and A. Chlyah (2005). Combined effect of 2,4-D and sucrose concentration on the genogenetic response in durum wheat. $A L-$ Awamia, (1- 3): $15-27$.

Ayed, O . S ; Trifay ; S . Ayed ; H . S . Amara ; J . Buyser and E . de picard (2010). Production of doubled haploid in tunisian durum wheat (Triticum Durum Desf.) cultivars through unpollinated ovary culture. Plant Mutation Reports, 2( 2): $33-39$.

Bajaj, Y. P. S. (1990). Haploid in crop improvement. Vol. 12 (encyclopedia).

Erezhenov, A. E. ; S. K. Mukhamedzhanov ; S. Zh. Kolumbaeva ; E. D. Azimova and N. D. Omirbekova (1991). Culture of unfertilized wheat ovaries: effect of genotype and phytohormons. (Russian) Aktual, nye Problemy Sovremennoi biologii, 23 -24.

Henry . $\mathbf{y}$ and $\mathbf{J}$. de Buyser (1985). Effect of the IB/IR translocation on the anther culture ability in Wheat (Triticum aestivum L.) Plant Cell Rep., 4: 307- 310.

Madarhri - Alaoui - M. ; M. Saidi ; A. Chlyah and H . Chlyah (1998). Green haploid plant formation in durum wheat through in vitro gynogenesis. Comptes Rendus de L Academe des Sciences Serie, 111, Sciences de la vie, 321(1): 25 - 30.

Salma - Ayed, O and H . Slim - Amara ( 2007). Production of doubled haploid in durum wheat ( Triticum Durum Desf.) through of un pollinated ovaries. Plant cell, Tissue and Organ Culture, 91 (2): 125- 133.

Sibi, M ; A . Kobaissi and A . Shekafndeh ( 2001 ). Green haploid plants from unpollinated ovary culture in tetraploid wheat (Triticum durum Defs.). Euphytica, $122(2$ ): 351 - 359.

Tsegaye Getahun ; Tileya Feyissa and Likyelesh Gusa ( 2013 ). Regeneration of plantlets from unpollinated ovary cultures of Ethiopian wheat (Triticum Turgidum and Triticum aestivum). Academic Journal, 12 (39): 5754 - 5760. 


\section{إنتاج نباتات أحاديه بإستخدام تقتية زراعة المبيض القها في القمح}

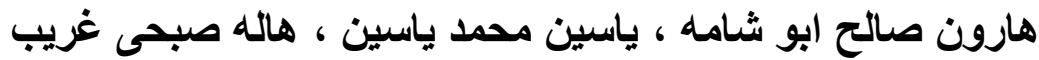

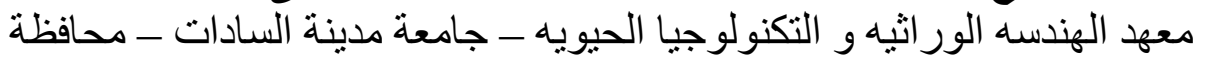

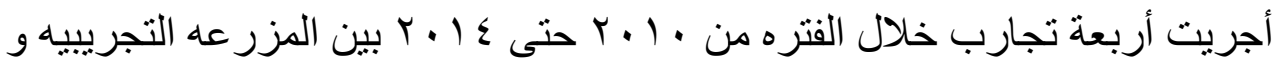

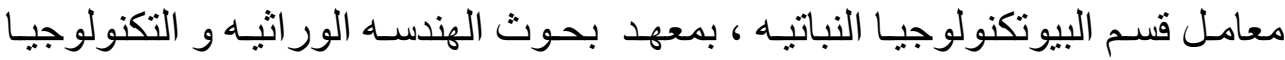

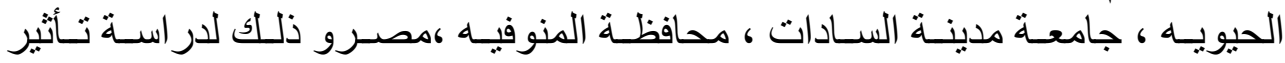

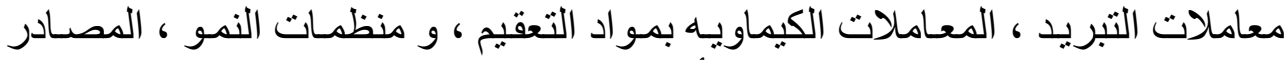

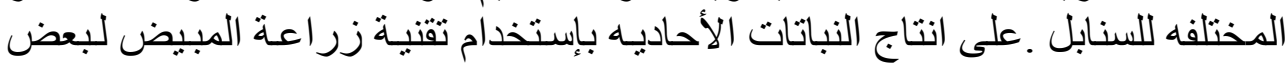

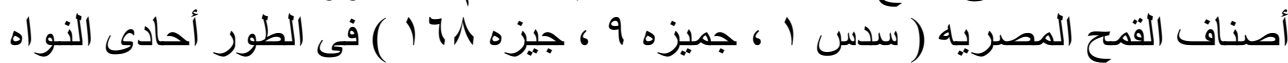

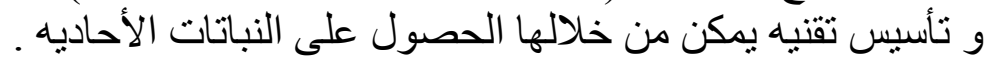

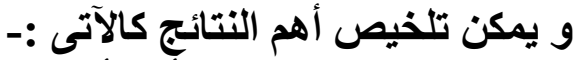

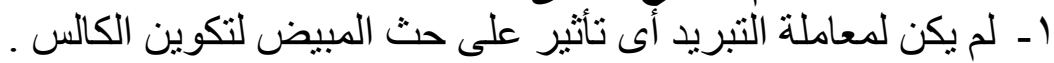

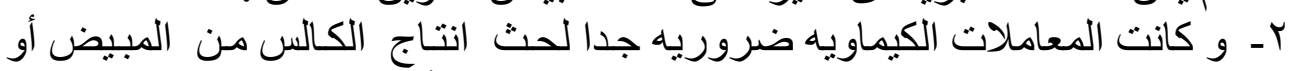

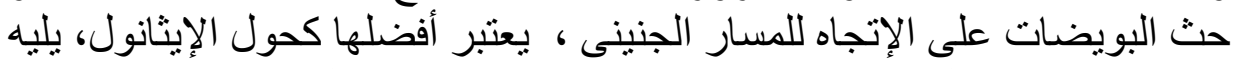

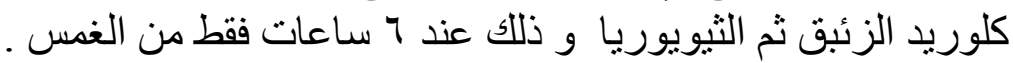

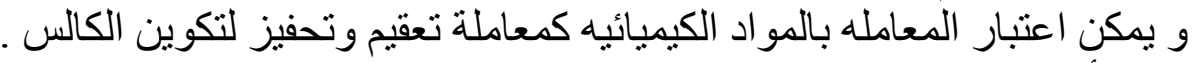

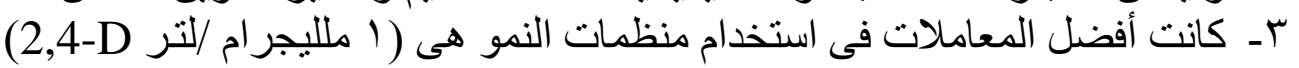

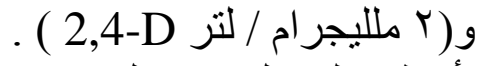

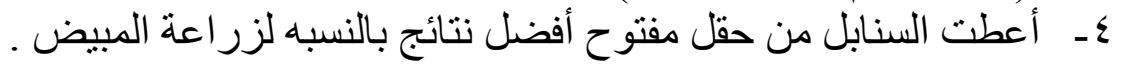

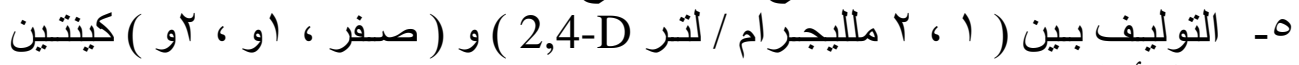

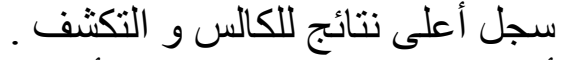
7 ـ أعطت سنابل الصنف سدس ا أعلى عدد للكالس بينما كان الصنف جيزه

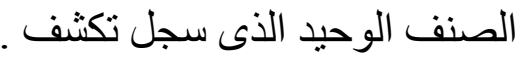
وتقترح هذه الاراسه:

- بأنه تختلف الإستجابه لزر اعة المبله المبيض بـإختلاف الأصناف حيث كان الصنف جيزه

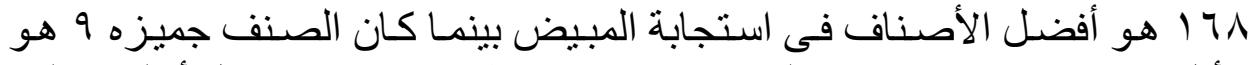

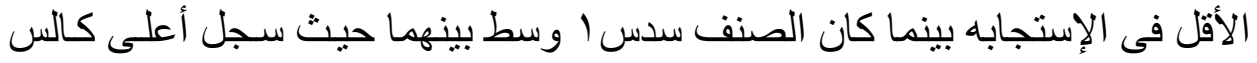

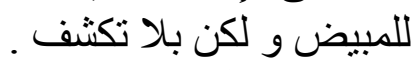
- تكر ار تكون الكالس يعتبر منخفض بالكن بالنسبه للمبيض. 